\title{
The Building of Character Nation Based on Islamic Religion Education in School
}

\author{
Aries Abbas, Marhamah Marhamah, Ahmad Rifa'i \\ Islamic University of Jakarta, Indonesia \\ Islamic University of Jakarta, Indonesia \\ SMP Muhammadiyah 13 Jakarta, Indonesia \\ Email: ariesabbas@paramout.co.id, marhamahsyarif2@gmail.com, and 3azka2thn@gmail.com
}

\section{ARTICLE INFO}

Date received : 03 January 2021

Revision date : 02 February 2021

Date received : 01 March 2021

Keywords:

National Character

Religious Education

School

\begin{abstract}
The character of a nation is a benchmark of the success of education in a nation and state. Because in essence the main purpose of education is to make humans mature. Meanwhile, Islam is a religion that emphasizes the importance of the formation of the character, because the Prophet Muhammad actually said I was sent to perfect morals. The purpose of this research is to find out about how to build the character of a nation based on Islamic education. Implementation of Islamic learning in schools in Jakarta. The focus of the application of Islamic religious education materials that can improve the character of the nation. The research methodology used is a descriptive qualitative research method using data sources from the literature review and field research directly to the school. Research finding that the quality of Islamic education that is integrated with all existing lessons will have an impact on the nation's character. National education is realized in creating people who have faith and are dedicated to God who is almighty, independent, honest, healthy, able to keep up with the times and be responsible.
\end{abstract}




\section{INTRODUCTION}

It is realized that education in Indonesia that has been going on for decades since its independence puts more emphasis on the cognitive dimension, creating intelligent, skilled, and adept human beings, which has the potential to give birth to people with broken personalities and integrity. It is not surprising that lies, manipulation, corruption, greed, collusion, nepotism, ethnic riots, murder and a series of other incidents always color the news in this country. (Sofyan, 2015). Other dimensions such as affective and psychomotor fail to be implemented in the education system as professional features that integrate intellectual, moral, and spiritual aspects are not reflected in the graduates. The identity crisis colors individuals who are born from the world of education and tend not to be confident about being themselves. The great wave of modernity has brought anyone, including the world of education, to follow the mainstream by making adjustments on the grounds that they do not want to be alienated and are said to be allergic to modernity. . In these conditions, the hegemony of western-style educational concepts is difficult to avoid, tends to ignore local concepts and teachings even though they are believed to be conditional on moral values. This is an indication that education in Indonesia has betrayed its mandate because it fails to maintain the values that are rooted in society.

The education sector, which is expected to provide enlightenment and shape the national identity, is experiencing an internal crisis and losing orientation. (Thamrin \& Ali, n.d.). A clear and consistent concept in its implementation always fails to find its totality

Critical reflection and comprehensive evaluation are not sufficiently carried out. Political changes in this country always sacrifice the concept and system of education so that the continuity of educational programs never runs smoothly. Ironically, every change of minister always gives birth to new policies which actually do not have an adequate philosophical basis. Education seems to be a means of political struggle for elitists and is used as a means of defending certain classes. Not to mention that currently there is a discourse on two-track education policies that seem very essentiality and it is feared that social segregation will lead to pros and cons. People no longer have the opportunity to enjoy quality education because they are in "poverty and ignorance". (Ahmad, Wasay, \& Jhandir, 2012). Education has betrayed its main mission to educate the nation's life without discriminating social status. However, in reality education is currently more busy serving certain social groups and being loyal servants of capitalism. The materialization of education has begun to emerge and shift the ideology of education towards the ideology of capitalist materialism. The curriculum is structured and oriented to be able to get a job wrapped in the clothes of modernity. Consequently, to enjoy it requires a large cost. In fact, modern theory says education is an investment and economically as a capital that will be reaped. Thus, realizing a human being who is completely and not marginalized will be difficult to achieve because economic principles do not recognize the terms spiritual, morality and togetherness. Moral values are taught only in theory and have never been proven in the practice of life.

In the context of education, capitalist practices and moral violations are ironically also committed by some people and educational institutions by making them their authority to increase income. The success of an educational institution is always measured by the magnificence of the building, the high cost, the number of enthusiasts and how many alumni become officials. (Aminah, 2015). This materialization of education is the initial basis for materialization in all aspects of life. Self-identity as a nation that likes to work together, helps each other and kinship is torn apart because all relationship patterns are measured in material terms.

Therefore, the State of Indonesia needs human resources in sufficient quantity and quality as a pioneer in elevating the dignity of the nation. To fulfill these human resources, education must be returned to its function. This is in accordance with Law No. 20 of 2003 on the National Education System. Article 3 of the law states that national education has the function of developing capabilities and shaping the dignified character and civilization of the nation in the context of developing the intellectual life of the nation. The national education system has been perfected and adapted to the development of scientific and technological advances and socio-cultural conditions. In it, it is full of educational principles based on national unity and integrity, upholding the national personality with dignity and morals, creativity, skills, and so on.

In a historical perspective, the existence of formal educational institutions such as Islamic schools today, is an accumulation of various kinds of cultural and educational traditions that have developed in Indonesian society. Starting from prehistoric or original traditions, Hindu Buddhist traditions, Islamic traditions, and Western or modern traditions. (Aminuddin, 1995) (Aminuddin, 2019). Therefore, Islamic schools have become one of the forms of Indonesian nation's cultural entities that have undergone a relatively intensive socialization process, and in quite a long time it has played a separate role in the stage of the formation of national civilization. 
But in reality, Islamic educational institutions, such as Islamic boarding schools and Islamic schools, initially received less attention from the community, especially the upper middle class community. (S Sutarman, Edi Hermawan, \& Ahmad, 2017). This is because these educational institutions are considered not able to accommodate the interests and demands of the community related to the development of students in preparation for life in the future, Islamic educational institutions so far are still struggling in the realm of halal, haram and surge hell without trying to touch on the worldly aspects. which indeed by classical Islamic thinkers must be shunned. Moreover, the existence of Islamic educational institutions, since its birth and development are generally located in rural and puritan areas, which when examined the majority of rural population with lower economic class with a pattern of life in farming (agriculture). In urban areas, Islamic schools were initially difficult to be able to develop or in other words, were less attractive to urban communities. And when talking about Islamic schools, it means talking about the tradition of village life which is static and monotonous.

Islamic educational institutions, Islamic schools that have historically been running for a long time, but are still considered not able to provide maximum hope for the community, especially Muslims. (S Sutarman et al., 2017). Islamic schools which number in the tens of thousands and spread throughout Indonesia are still considered unable to develop like other formal educational institutions such as schools. The quality of graduates of Islamic schools is always inferior to the quality of graduates of schools. Incorrect management of the Islamic school education system.

Facing these complex problems, Muslims seem to have to be willing to reconstruct teaching patterns and the curriculum that they use. So far, Islamic educational institutions are managed traditionally and allowed to run without direction and purpose so that the resulting graduate competencies are not optimal.(Hidayat, 2015). There may be many successful and successful graduates of Islamic education institutions either as officials or as entrepreneurs, but their numbers are also directly proportional to moral immorality through the practice of corruption, collusion and nepotism or also a culture of elbowing and lobbying with a transactional system. Even though we realize it or not, education in Islam has covered all aspects of education. Islam not only emphasizes the aspect of understanding the concept, but rather Islam emphasizes the realm of moral or affective. Education in Islam aims to shape human morals to be commendable. In accordance with the Prophet actually I was sent only to perfect the morals.

If these Islamic morals can then be integrated into a good education pattern, the products of Islamic school graduates will have pious morals.(Satori \& Komariah, 2009). Students are not only good at cognitive but also able to be role models and role models in social, national and state life.

\section{LITERATURE REVIEW}

1. Understanding The Character of The Nation

The linguistic character comes from the Latin character, which means, among other things: character, character, psychological traits, character, personality or morals. (Sutarman Sutarman, Parjiman, \& Chirzin, 2020). Because the character of a system and habits that direct the actions of an individual, as well as a collection of values that lead to a system, which underlies the thoughts, attitudes, and behaviors that are displayed as a reflection of the national character.

The character in Islamic philosophy is the character closer to morality, namely the spontaneity of humans in behaving, or doing actions that have been integrated in humans so that when they appear, a good character will emerge that does not need to be thought about. (Anggraeni, Herlina, \& Astari, 2017) (Lestari, Yuni., 2017). That character is a collection of systems of behavior, character, and morals that are born from life habits. In the mechanism, there are 3 elements that make up human character, namely during childhood, the environment and science

Of these elements, the first and second elements have many roles in the formation of human character. A simple illustration is that when we were little, we were among the children who were often scolded by their parents, lied to by them and scared by something because we obeyed their orders. (Mahsun, 2013). Then it is likely that we will have a character that is arrogant, rude and timid. Likewise with the environment which is very influential for our personality or character. A good environment will form a good character in us which comes from our habitual habits that we do in our daily lives.

a. In the Islamic perspective, noble character or character is the result of the process of implementing shari'ah (worship and muamalah) which is based on a solid foundation of aqidah. (Sukmadinata, 2012). Like a building, character or character is the perfection of the building after the building foundation is strong. Islamic character is a character based on the Islamic religion, namely a series of normative human 
behavior, both as an individual being and a social being, whose norms are derived from the teachings of Islamic teachings, which are sourced from the Al Quran and As Sunnah.

b. A Muslim who has the correct aqidah or faith will certainly manifest in his attitudes and behavior in everyday life which are based on his faith, it will manifest in the Muslim person an Islamic character if it has this aspect. The character of Islam itself is, like what the Prophet Muhammad has exemplified. (Al-Ahzab verse 21). Indeed, the Messenger of Allah is a good example to you; For those who expect Allah and the Hereafter and who remember Allah a lot. Therefore, the character must combine cognitive, affective and psychomotor aspects. Rasulullah SAW has provided that example by building education based on morals and ethics as stated by Allah in Surah Al-Ahzab verse 21.

2. Definition of Islamic Education

Education can be interpreted narrowly, that is guidance given to children until they are adults.(Rohmawati, 2015). While in the broadest sense is everything that concerns the process of human development and development, namely efforts to instill and develop values for students, so that the values contained in education become part of the personality of a smart child, good, able to live, useful for the community. Education is a business that is carried out with full of awareness aimed at the safety and happiness of humans.

Islamic Religious Education is as a guide to spiritual and physical growth according to the teachings of Islamic Religion with the wisdom of directing, teaching, training, nurturing, and overseeing the implementation of all Islamic teachings. (Juhji., 2016). The term guides, directs and nurtures and teaches and trains, implies an effort to influence the souls of students through a level-by-level process towards the goals set, namely instilling piety and morals and establishing the truth, so that human beings are formed who are personal and virtuous. (Surah Al-Baqarah: 31) There are three important points of character, namely:

a. Islamic Education involves aspects of the physical and spiritual, because both are a unity that can not be separated, therefore coaching of the two must be balanced.

b. Islamic Religious Education bases its conception on religious values. This means that Islamic religious education does not ignore theological factors as a source of knowledge itself. (Ambarwati, 2018) c. The existence of the element of piety as a goal to be achieved, as we know that piety is a fortress that can function as a deterrent to negative influences that come from outside.

Based on the above understanding that Islamic education is guidance given by a person so that he develops optimally in accordance with Islamic teachings. (Afandi, 2014). So the planning of Islamic religious education learning systems is a thought and preparation to carry out teaching objectives through the steps in learning that become a unity consisting of components or elements that interact with each other, interrelated, or interdependent to form a complex whole into an organized combination includes various interrelated and interconnected elements to achieve the objectives of Islamic religious education learning

\section{METODE}

The methodology of this research is to use a descriptive qualitative analysis method by collecting data obtained through informants, deliberately selected, the object of research on the problem to be examined. (Sugiyono, 2014). Further information is sourced from the informant as preliminary information, in order to provide more accurate and complete information, the informant is asked to provide detailed data information.

The research subjects consisted of several volunteers who provided information in the completeness of the data needed by researchers, namely the principal, teachers and committees. The number of research subjects do not use random samples and also do not use populations and large samples, this study uses samples that fit the research paradigm (Nasrudin, 2019). And will continue to grow in accordance with the completeness of the required data, Source of data needed is primary data and secondary data, so that the research becomes valid and the data collected is complete both primary data and secondary data. (Narti, 2019).

1. Primary data were obtained from school principals, teachers, education staff, and school committees. In the form of words, attitudes or actions obtained through interviews, questions and answers, observations, directly or indirectly, the relationship with building the character of the nation based on religious education in schools.

2. Secondary data obtained from documents in the form of tables, daily notes, minutes of meetings, photographs, video recordings, the internet, as primary data supporting data, while 
secondary data to support the data needed in research.

\section{RESULTS AND DISCUSSION}

1. Character development personality

Fostering personality in character or whole soul may only be formed through environmental influences, especially education. (Kholis, Karimah, Tarbiyah, \& Iain, n.d.). The targets pursued or addressed in the formation of this personality / character are personalities that have noble character and the degree of moral success is closely related to the level of faith.

In shaping a person's character, every teacher should realize that character building is very much needed coaching and moral practices in students, not only taught theoretically, but must be taught in the direction of practical life. Religion as an essential element in human personality can provide a positive role in the journey of human life, in addition to the truth it can still be believed absolutely. In terms of shaping one's character, religious education has a very important role in life. Religious education acts as a controller of behavior or actions that are born from a desire based on emotions. If the teachings of religion are used to be used as a guide in one's daily life and have been inculcated since childhood, then his behavior will be more controlled in dealing with all the desires that arise. (Kholis et al., n.d.). We already know that many children have bad personalities which result in moral decline. How important religious education is to a person, and how much danger there is due to the lack of religious education. For that, we need to find a way that can lead us to guarantee the personality that can create and maintain the peace and happiness of society and the nation in the future.

Therefore to form a character based on religion is first determined by the family first, because the family has an important role in educating religion for their children, especially in forming personality or character. This means that families are obliged to introduce and invite children and other family members to religious life as early as possible. Religion gives a lot of good teaching in shaping one's personality, for example a child will be polite to an older person compared to him, that's because parents have taught kindness early on to their children, so the child will not change his character into someone else. (Zahroh, 2015).
Because it has become a Shari'a in religion. Religion often gives us an overview of the formation of better character.

So, education has a close relationship with Religion, so that Religion is used as a foundation for the formulation of education, and religious education has a major influence in the formation of morals and character of students. (Agustinova, 2015). Therefore parents / educators must pay attention to the following matters:

a. Religious education should be given to children as early as possible, teach from small things in accordance with religious guidance.

b. Religious education lessons are not merely science, but practical knowledge is included in it.

c. Children tend to follow what they see from adults, therefore parents should be accustomed to daily behavior with moral values, both words and deeds.

Religious education in the world of education is the basic capital for children to obtain divine values, that how important religious values are taught to children, which in the world of education is included in one area of work, namely religious education. Religious education in life is not entirely the responsibility of teachers in schools, but also parents as a real example in the lives of children. (Universitas \& Kuala, 2017).How is it possible for children to be of good character, if their parents live in unkindness. Therefore religious education must be instilled in children wherever he is, both formal and non formal.

Then whether religious education can shape the morals and character of students? To answer this question many elements are included. Theoretically religious education should be able to shape the personality or character of children, this is in accordance with the ultimate goal of religious education, which is to have faith and devotion to God Almighty. (Parisi, 2017). If someone has faith and devout in truth, then all his actions will reflect religious values, carry out everything that is ordered and leave everything that is prohibited. Along with that, morals / character / ethics will also be reflected in it. How can someone who has faith and piety for example, use drugs or other things that are forbidden by religion. This is proof that if a child has embedded himself strong religious values, then it is certain that the moral / character / ethics of that person will be formed by themselves, following the rhythm of faith and the quality of piety that is in him.

2. Character Building as Islamic Religious Education 
The concept of character education is a prophetic task, because the Prophet Muhammad was sent to perfect morals. (Aceng Lukman Nulhakim, Mulyanto, \& Sumerhu, 2020) substantially, character is the same as morale because they both discuss human actions. Imam Al-Ghazali explained that morality is something that is used so that when someone does something spontaneously the character will.

Moral is often also called knowledge of behavior, because with this knowledge everything will be obtained about the goodness of the soul, as well as how to cleanse a dirty soul.(A.L. Nulhakim, Sutarman, Ismail, Noer, \& Tohir, 2020).

The basis between character and character above implies the same substance of meaning, namely the moral problem of humans; about knowledge of good values, which should be owned by someone and reflected in every behavior and actions. This behavior is the result of his own awareness. (Januarti, 2017). Someone who has good values in his soul and can apply them in everyday life is called a person of good character or character.

Morals or character in Islam is the main target in education.(Diyanti, 2012) (О.В.Ковалишина, 2017) (Jaya, Syafril., Fitrah., 2017). This can be seen from a number of prophetic traditions that explain the virtues of moral education, one of which is the following: "Teach your children good, and educate them". The concept of education in Islam views that humans are born with outward potential, namely:

a. The potential to do good to nature,

b. The potential to do damage to nature,

c. The potential of divinity that has nonphysical functions.

Morals are always the main target of the educational process in Islam.(Aceng Lukman Nulhakim et al., 2020). Because morals are considered as the basis for the balance of human life which is a determinant of success for other pedagogical potentials. The moral principle consists of four things:

a. Wisdom is a psychological situation where a person can distinguish between right and wrong.

b. Syajaah (truth) is a psychological state in which a person vents or holds the potentiality of emotional aspects under the control of reason

c. Iffah (purity) is controlling the potentiality of tastes or desires under the control of reason and sharia

d. 'Adl (justice) is a psychological situation that regulates the level of emotions and desires according to the needs of wisdom when releasing or venting

3. Moral principles in Character Education

The above moral principle asserts that the nature of the human soul consists of the potential for good lust and the potential for bad lust, but through education it is hoped that humans can practice to be able to control the tendency of their actions towards good lust. (Pohan., Rahmad Asril., 2014). Therefore Islam prioritizes the educational process as an agent for the formation of morals in children. Islam always positions the formation of character or character of children on the main pillars of educational goals. To realize the formation of morals in children al Ghazali offers an educational concept that aims to draw closer to God. According to him closer to God is a benchmark of human perfection, and to get there there is a bridge called science.

Specific material for teaching morals, but material in moral education can be implemented in many sciences as long as the main purpose is to serve God.(Sofyan, 2015). The opinion above illustrates that morals are the main pillar of the goals of education in Islam, this is in line with the background of the need to apply character education in schools; To create a large, dignified and respected nation by the world, a good society is needed starting from character building. One of the ways in which character or character development can be done is through the education process at school by implementing the inculcation of moral values in each subject matter.

Schools as a vehicle for learning undoubtedly play a large role in the development of student character. The school has brought children and adolescents to complete their developmental tasks well into adulthood. (S Sutarman et al., 2017). In this school, the child's brain, heart, and body are developed to be more intelligent, sensitive and healthy. But in the implementation of character education in schools, in the implementation still found several problems, because the development of the era of children is far different from the previous children. Here are some obstacles in shaping the character of children in schools including;

a. Influence of Television / Internet / Advances in abused technology. A variety of television programs can have a negative effect if not accompanied by parents of students.(Sutarman Sutarman \& Hanafiah, 2020). Television today is no stranger to domestic life. Nor are luxury items that 
can only be owned by certain people. But now television is like a necessity that every family must have. It is undeniable that the role of television is also big in the era of increasingly fast information technology. What we can get is to use it as a source of knowledge, broadcast information faster than other media, and add useful new vocabulary. But of course mudharatnya still exist maybe even greater than the benefits, the rest are things that are in vain can even damage the mind.

b. Community Environment, Society in the community with friends can affect morals Environment is very influential for the development of children's character. (Utami, 2014). If the child is in a good environment, it will be able to have a good influence on the development of the child's character, and vice versa, a bad environment can also have a bad influence on the child's character development. As parents must be observant and smart to choose a good environment for children, because it will determine the development of your child's character. This environment can be assumed like the environment where you live, your child's play environment, or your child's school environment.

c. Not synchronous education or rules at school and at home a rule that is applied at school must also be applied at home if otherwise it will hinder the purpose of forming the child's character. (Sutarman Sutarman \& Hanafiah, 2020). Students can only watch TV on Saturdays - Sundays accompanied by parents.

d. The role of the teacher can not be an example of the values of the character chosen. The most severe problem is the role of the teacher to be an example in realizing character values specifically in accordance with the subject's character values and general character values in schools.(Yarmand et al., 2017). Less examples of exemplary Teachers and parents are the main factors in shaping the character of children, exemplary crises of both can lead to bad behavior.

e. Schools have not been able to choose character values in accordance with their vision. The number of character values is so numerous that the school faces difficulties choosing which character values are in accordance with the vision of the school. (Parisi, 2017). This has an impact on the movement to build character in schools to be less focused and focused, so it is not clear also monitoring and assessment.

$f$. The lack of teaching hours of Islamic education in public schools, so, understanding of religion for students in public schools is very minimal. (Zulfitria, Dewi, \& Gunadi, 2019). In one week, there were only three hours of religious subjects being imposed in public schools. This is considered still lacking, it is proven that there are still many school-age children who cannot read and write the Koran, including the basic teachings of religion.

The description above illustrates that education is the best way to make changes in shaping the character of the nation, and the most important process is in Islamic religious education, but so far Islamic religious education in schools is only taught as knowledge and not applied in everyday life.(Sutarman, Widiastuti, Badriatin, Arofah, \& Syahriani, 2020).

The emergence of the paradigm that Islamic Education (PAI) is not one of the materials that become graduation standards for students also influences the depth of learning.(Zulfitria et al., 2019). This causes PAI to be considered unimportant material and only complements learning, and even PAI learning is only done in class, which only gets 2 hours of study time every week, even more ironic PAI evaluation is only done with written tests.

The learning pattern of the PAI material above is time to change. Teachers who spearhead the success of a learning must realize that their responsibility towards the success of PAI learning is not only on the cognitive level. (S Sutarman et al., 2017). But no less important is how to give awareness to students that religious education is a necessity so that students have high awareness to carry out the religious knowledge they obtain in their daily lives. Teacher creativity is needed in conveying learning, where PAI learning should not only be taught in the classroom, but how teachers can motivate and facilitate religious learning outside the classroom through religious activities and create a religious school environment that is not limited by school hours.

PAI learning is the formation of students' personalities reflected in their behavior and mindset in daily life, so PAI learning is not only the responsibility of PAI teachers alone but it needs harmonious cooperation between parents, the community and the school. (Yahya., Imam., 2013). Schools must be able to communicate the ways and strategies of Islamic religious learning to all parties 
to become a holistic and harmonious collaboration for the formation of high moral and virtuous students.

The success of PAI learning at school is also determined by the application of appropriate learning methods. In line with this Abdullah Nasih Ulwan provided the concept of inluentive education in children's moral education consisting of:
a. Education by example,
b. Education with customs,
c. Education with advice,
d. Education by giving attention,
e. Education by giving punishment

Teacher professionalism is determined by intelligence, religion, morals, charisma and authority. Therefore one of the important educational processes is exemplary. Teacher behavior and behavior is a valuable learning mirror for students. (Haryono, 2016). The principle "ing ngarso sung tulodo ing madyo mangun karso". Namely in front of the example, in the middle of providing guidance and behind giving encouragement. This example is one of the methods teachers should apply in PAI learning. Teachers must be able to apply religious values in their lives before teaching these religious values to students. Because it will be a real model for students. Education related to personality or morals cannot be taught only in the form of knowledge, but there is a need for habituation in daily behavior. After being a good example, the teacher must encourage students to always behave well in everyday life.

The teacher must also give an appreciation of the practice of student character, both at home and at school. Form of teacher appreciation for student achievement is a positive feedback that is by giving rewards and punishment (reward-punishment). (Sutarman Sutarman \& Hanafiah, 2020). The reward is given as a teacher's appreciation of student achievement while the punishment is given if the student violates the rules that have been determined, but the punishment here does not mean by violence or demeaning the student's mentality, but rather the punishment that is educational. Reward and punishment methods are needed in PAI learning with the aim that children are always motivated to learn. Provision of knowledge about true aqidah is the most basic basis in the cultivation of morals in children.

The importance of learning Islamic education in schools, because religious education is the foundation for learning other knowledge, which will deliver the formation of children who are personality, religious and highly knowledgeable. (Maya, 2017). So it is appropriate to say that the application of Islamic education in schools is the main pillar of character education. . Religious education teaches the importance of moral cultivation which began in childhood. He teaches aqeedah as the basis of religion, teaches the Qur'an and Hadith as a guide to his life, teaches fiqh as a guide in worship, teaches Islamic history as an example in life, and teaches morality as a guide to his life's behavior, so that someone knows which actions are good and which actions are bad.

\section{CONCLUSION}

Planting characters in children from an early age means participating in preparing the nation's generation of character,they are the future generation of the nation who are expected to be able to lead the nation and make it a civilized nation, uphold the nation's noble values with good character and character and become a knowledgeable generation. high and adorn himself with faith and piety. Therefore learning Islamic religious education (PAI) in schools as an effort to shape student character is very important.

An indicator of the success of character education is if someone already knows something good is cognitive, then loving the good is affective, and then doing good is psychomotor. The above description reinforces the importance of character education in children carried out early on, because a person's character emerges from a habit that is repeated over a long time and there is a role model from the surrounding environment. One of the habits that can be done is from the habit of religious behavior of children with the support of the school, community and family. While the efforts that can be done by schools in maximizing PAl learning in schools include:

a. Teachers who are professional in the sense of mastering in their knowledge, moral and able to be role models for their students,

b. Learning is not only done in the classroom but coupled with religious extracurricular activities carried out seriously as part of learning,

c. Obliging students to carry out certain worship services at school with the guidance of the teacher (for example routinely performing the midnight prayer),

d. Provide a suitable place of worship for religious activities,

e. Familiarize good morals in the school environment and carried out by the entire school community (eg greetings, greetings, and smiles),

f. All teachers should be able to implement religious education in the overall material taught as a form of overall character education.

If some of these things can be realized, the goal of national education in creating Indonesian people who believe and devote to 
the almighty, responsible, independent, honest and democratic God will be realized..

\section{REFERENCES}

Afandi, M. Zainul. (2014). Penanaman Karakter Semangat Kebangsaan Dan Cinta Tanah Air Dalam Kegiatan Ekstrakurikuler Hizbul Wathan Di Sekolah Menengah Pertama (Studi Kasus SMP Muhammadiyah 4 Surakarta Tahun Pelajaran 2013/2014). Universitas Muhammadiyah Surakarta.

Agustinova, Danu Eko. (2015). Hambatan Pendidikan Karakter Di Sekolah Islam Terpadu (Studi Kasus Sdit Al Hasna Klaten). ISTORIA: Jurnal Pendidikan Dan IImu Sejarah, 10(1), 12-18.

https://doi.org/10.21831/istoria.v10i1.3598

Ahmad, Muhammad Bilal, Wasay, Ejaz, \& Jhandir, Saif Ullah. (2012). Impact of employee motivation on customer satisfaction: study of airline industry in Pakistan. Interdisciplinary Journal of Contemporary Research in Business, $4(6), 531-539$.

Ambarwati, Eka. (2018). Pengembangan Potensi Pariwisata Religi (Studi Kasus Pada Makam Kyai Ageng Sutawijaya di Desa Majasto Kecamatan Tawangsari Kabupaten Sukoharjo). $12 . \quad$ Retrieved from https://www.google.com/url?sa=t\&source =we b\&rct=j\&url=http://eprints.ums.ac.id/68947/1 6/NASKAH\%2520PUBLIKASI-

16. pdf\&ved=2ahUKEwjopuK6n9rmAhut7XMBH eDMB8kQFjAFegQIARAB\&usg=AOvVaw1YYBih eMMsprMW5mNHAwd1

Aminah, Siti. (2015). MERAJUT UKHUWAH ISLAMIYAH DALAM. Jurnal Cendekia Vol, 13(1).

Aminuddin. (1995). Stilistika: pengantar memahami bahasa dalam karya sastra. IKIP Semarang Press.

Aminuddin, M. Yusuf. (2019). Perubahan Status Kelembagaan pada Perguruan Tinggi Agama Islam dalam Menghadapi Tantangan dan Peluang Pendidikan Islam di Indonesia. Talim: Jurnal Studi Pendidikan Islam, 2(1), 22-44.

Anggraeni, Devia Putri, Herlina, Hera Nurmayani, \& Astari, Ruri Yuni. (2017). GAMBARAN PENGGUNAAN KB DI DESA HAURSEAH KECAMATAN ARGAPURA KABUPATEN MAJALENGKA TAHUN 2017. Syntax Literate; Jurnal IImiah Indonesia, 2(12), 9-21.

Diyanti, Dwitasari. (2012). Strategi Marketing Public Relations Dalam Proses Rebranding. Skripsi.
Haryono, Azis Fathoni Indra Yugusna and Andi Tri. (2016). Pengaruh Gaya Kepemimpinan Demokratis Dan Lingkungan Kerja Terhadap Kinerja Dan Kedisplinan Karyawan (Studi Empiris Pada Perusahaan SPBU 44.501.29 Randu Garut Semarang). Journal Of Management, 23.

Hidayat, Nur. (2015). Peran dan Tantangan Pendidikan Agama Islam di Era Global. Jurnal Pendidikan Agama Islam, 12(1), 61-74.

Januarti, Rini. (2017). Implementasi Penilaian Sikap Spiritual Dalam Pembelajaran Tematik Di Kelas IV Sekolah Dasar Islam Al-Azhar 21. 1-9.

Kholis, Nur, Karimah, Rofikatul, Tarbiyah, Fakultas, \& Iain, Keguruan. (n.d.). LINGKUNGAN HIDUP

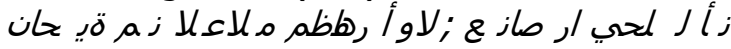

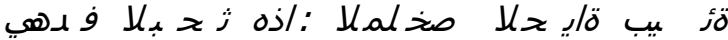

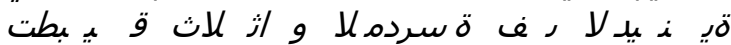
Tegalasri

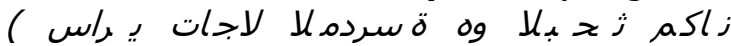

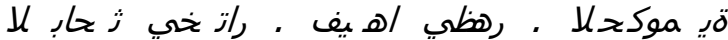

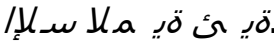

Mahsun, Ali. (2013). Pendidikan Islam dalam arus globalisasi: Sebuah kajian deskriptif analitis. Epistemé: Jurnal Pengembangan IImu Keislaman, 8(2), 259-278.

Maya, Rahendra. (2017). Karakter (Adab) Guru dan Murid Perspektif Ibn Jama'ah Al-Syafi'í. Edukasi Islami: Jurnal Pendidikan Islam, 6(02), 33.

Narti, Sri. (2019). Kumpulan Contoh Laporan Hasil Penelitian Tindakan Bimbingan Konseling (PTBK). Deepublish.

Nasrudin, Juhana. (2019). Metodologi Penelitian Pendidikan: Buku ajar praktis cara membuat penelitian. Pantera Publishing.

Nulhakim, A.L., Sutarman, Ismail, K., Noer, R. M., \& Tohir, T. (2020). Professional teacher competencies in optimizing science for extracurricular activities: Case study of SDN Dadap III Tangerang Regency. Test Engineering and Management, 83(May).

Nulhakim, Aceng Lukman, Mulyanto, AgusIwan, \& Sumerhu, Herru. (2020). Multicultural Education in Schools and Its Relevance to Community Social Life. IJO-International Journal of Educational Research, 3(02), 31-43.

Parisi, Salman Al. (2017). Tingkat Efisiensi dan Produktivitas Lembaga Zakat di Indonesia. Esensi,

71). https://doi.org/10.15408/ess.v7i1.3687

Rohmawati, Afifatu. (2015). Efektivitas Pembelajaran. Jurnal Pendidikan Usia Dini, 
$9(1), 15-32$.

Satori, Djam'an, \& Komariah, Aan. (2009). Metodologi penelitian kualitatif. Bandung: Alfabeta, 22.

Sofyan, Aris. (2015). Pengaruh Kematangan Emosi terhadap Sikap Tasamuh. MUDARRISA: Journal of Islamic Education, 71$), 59$. https://doi.org/10.18326/mdr.v7i1.749

Sugiyono, M. (2014). Educational Research Methods Quantitative, Qualitative Approach and R\&D. Bandung: Alfabeta.

Sukmadinata, Nana Syaodih. (2012). Metode Penelitian Pendidikan, PT Remaja Rosdakarya. Bandung.

Sutarman, S, Edi Hermawan, H., \& Ahmad, A. (2017). Character education to build personal learners tough. IOSR Journal of Research \& Method in Education (IOSRJRME), 71), 5963.

Sutarman, Sutarman, \& Hanafiah, Hanafiah. (2020). STRATEGI PENGUATAN PENDIDIKAN KARAKTER PESERTA DIDIK. Nusantara Education Review, 3(1), 81-90.

Sutarman, Sutarman, Parjiman, Parjiman, \& Chirzin, Muhammad. (2020). the Education of Character of the Vocational High School of Pleret Bantul Yogyakarta Indonesia. Educational Administration Research and Review, 4(1), 68-78. https://doi.org/10.17509/earr.v4i1.26196

Sutarman, Widiastuti, I., Badriatin, T., Arofah, I., \& Syahriani. (2020). Management of character education strengthening strategies in students. International Journal of Psychosocial Rehabilitation, 24(8). https://doi.org/10.37200/IJPR/V24I8/PR28019 9

Thamrin, M., \& Ali, Muhammad. (n.d.). Peningkatan Tanggung Jawab Melalui Metode Pemberian Tugas Pada Anak Usia 5-6 Tahun.
Tanjungpura University.

Universitas, Pascasarjana, \& Kuala, Syiah. (2017). Pascasarjana Universitas Syiah Kuala 9 Pages KINERJA GURU PENDIDIKAN AGAMA ISLAM DALAM MENINGKATKAN. 5(1), 39-47.

Utami, Annis Titi. (2014). Pelaksanaan nilai religius dalam pendidikan karakter di SD Negeri 1 Kutowinangun Kebumen. S. Pd Skripsi. Universitas Negeri Yogyakarta.

Yarmand, Hooman, Zulkifli, Nurin Wahidah Binti Mohd, Gharehkhani, Samira, Shirazi, Seyed Farid Seyed, Alrashed, Abdullah A. A. A., Ali, Mohamad Azlin Bin, Dahari, Mahidzal, \& Kazi, S. N. (2017). Convective heat transfer enhancement with graphene nanoplatelet/platinum hybrid nanofluid. International Communications in Heat and Mass Transfer, 88, 120-125. https://doi.org/https://doi.org/10.1016/j.icheat masstransfer.2017.08.010

Zahroh, Lailatu. (2015). Pendekatan Dalam Pengelolaan Kelas. TASYRI': JURNAL TARBIYAH-SYARI'AH ISLAMIYAH, 22(2), 175189.

Zulfitria, Mrs., Dewi, Happy Indira, \& Gunadi, R. Andi Ahmad. (2019). The Role Of Teachers In The Millennium Era On The Development Of Student Creativities In Village Border Areas. 313(ICORSIA 2018), 37-40. https://doi.org/10.2991/icorsia-18.2019.10

О.В.Ковалишина, О. Р. Швабски. И. В. Ивано. (2017). Опыт аудита обеспечения качества и безопасности медицинской деятельности в медицинской организации по разделу «Эпидемиологическая безопасностьNo Title. Вестник Росздравнадзора, 4, 9-15. 